\title{
PERAN SEKRETARIS DALAM MEMPERLANCAR TUGAS PIMPINAN PADA DINAS PERINDUSTRIAN PROVINSI NUSA TENGGARA BARAT
}

\author{
Iwin Ardyawin ${ }^{1}$, Junaidi AM$^{2}$, Elva Ayu Lestari ${ }^{3}$ \\ Jurusan Ilmu Perpustakaan, Fakultas Ilmu Sosial dan Ilmu Politik \\ Universitas Muhammadiyah Mataram \\ iwinardyawin@gmail.com
}

\section{INFO ARTIKEL}

Riwayat Artikel:

Diterima: 13-Oktober-2019

Disetujui: -...-...

\section{Kata Kunci:}

Peran, Sekretaris, Tugas

\section{ABSTRAK}

Penelitian bertujuan untuk mengetahui bagaimana peran sekretaris dalam memperlancar tugas pimpinan Pada Dinas Perindustrian Provinsi Nusa Tenggara Barat. Penelitian ini menggunakan metode kualitatif, teknik pemilihan sampel yang digunakan adalah nonprobability sampling dengan purposive sampling. Informan penelitian ini adalah Sekretaris Dinas Perindustrian Provinsi Nusa Tenggara Barat. Penelitian ini menggunakan metode kualitatif deskriptif dengan pengambilan data dengan cara pengamatan, observasi dan wawancara mendalam.. Kemudian data tersebut dianalisis kembali dengan mengorganisasikan data, mereduksi data, dan menyajikan data dalam bentuk bagan, tabel, atau pembahasan secara deskriptif.. Hasil penelitian menunjukkan peran sekretaris dalam memperlancar tugas pimpinan dengan menjalankan peran terhadap atasan dan peran kepada bawahan.

\section{A. PENDAHULUAN}

Dalam melaksanakan tugasnya sehari-hari pimpinan dituntut untuk dapat mengetahui situasi dan kondisi organisasi dalam suatu sistem yang terpadu, dimulai dari level yang terendah sampai yang tertinggi. Hal ini memberikan konsekuensi bahwa seorang pemimpin harus cepat tanggap, tepat dalam mengambil keputusan bagi setiap situasi dan kondisi organisasinya, dapat memanfaatkan waktu secara efektif dan efisien, serta harus dapat memahami dan menguasai segala permasalahan yang timbul di lingkungan organisasinya.

Tidak sedikit dari sekian tugas pimpinan yang maha berat di atas, ada tugas-tugas yang dapat terselesaikan tapi ada juga tugas-tugas yang terabaikan bahkan acak-acakan. Oleh karenanya, untuk mempermudah/memperingan tugas-tugas tersebut dibutuhkan peranan seseorang untuk membantu meringankan beban pimpinan. Orang yang ditugaskan untuk membantu tugas pimpinan ini dituntut orang yang memiliki SDM memadai, cakap, mampu dan terampil dalam melaksanakan tugasnya, serta dapat diandalkan.

Dengan dibutuhkannya peranan seseorang untuk membantu tugas pimpinan dimaksudkan agar tugas-tugas pimpinan dapat dijamin kelancaran dan keberhasilannya. Untuk menjamin kelancaran dan keberhasilan tugas pimpinan, seseorang yang dibutuhkan tersebut adalah yang bertugas sebagai "sekretaris" yang tentunya sekretaris yang dimaksud adalah sekretaris yang mempunyai pendidikan khusus, terampil, punya kualifikasi dan bonafiditas yang baik, serta mampu mengetahui secara cepat dan tepat tugas-tugas pokok dari pimpinan organisasi. Untuk semua itu maka tugasnya sebagai sekretaris harus mencapai tingkat profesional yang berkualitas dan bertanggung jawab.

Menurut Braum dan Ramon (Dalam Saiman, 2002 : 24) mengatakan bahwa pengertian sekretaris 
adalah seorang pembantu dari seorang kepala atau pimpinan yang menerima pendiktean, menyiapkan surat-menyurat, menerima tamu, memeriksa atau mengingatkan kepala atau pimpinannya mengenai kewajibannya yang resmi atau perjanjiannya dan melakukan banyak kewajiban lainnya yang berhubungan guna meningkatkan efektivitas dari kepala atau pimpinannya mengenai kewajiban lainnya yang berhubungan guna meningkatkan efektivitas dari kepala atau piminan. Sekretaris merupakan cerminan dari sebuah organisasi. Dalam kedudukannya sekretaris adalah seorang asisten pimpinan yang sangat dipercaya untuk membantu menyelesaikan tugas pimpinan. Selain itu, sekretaris juga harus mampu menyesuaikan diri dengan tugas yang dilimpahkan pimpinan. Sekretaris profesional harus bertindak proaktif, ia harus mampu merencanakan dan melakukan tugas-tugasnya Sumanto \& Dwiantoro (2006: 2). Pelimpahan tugas ini dapat mengurangi pekerjaan pimpinan yang bersifat teknis spereti korespondensi, menyiapakan rapat, mengatur perajalanan dinas dan sebagainya. Bila pelimpahan tugas dapat dilakukan dengan baik oleh sekretaris, maka pimpinan dapat memusatkan perhatian dan tenaganya untuk melaksanakan tugas manajerialnya. Seperti tugas tugas perencanaan, pengorganisasian, penempatan staff dan mengawasi perusahan.

Dengan demikian pekerjaan sekretaris tidak hanya pekerjaan teknis keadministratifan atau mendampingi dan melayani kebutuhan pimpinan. Sekretaris bertranformasi menjadi sosok yang multifungsi dan profesional dalam bekerja, berkompeten dalam administrasian kantor, cerdas dalam menjalin hubungan kerja dengan orang lain, terampil dalam memberikan solusi, dan berorientasi untuk melayani seluruh pihak-pihak yang berkepentingan dengan organisasi (stakeholders).

Dinas perindustrian provinsi nusa tenggara barat memiliki sekretaris pimpinan yang memiliki peran dalam membantu memperlancar tugas pimpinan. Sekretaris pimpinan juga berfungsi sebagai penghubung antara pimpinan dan pegawai lain maupun pihak-pihak luar yang berkepentingan dengan pimpinan dan juga sebaliknya. Selain itu sekretaris juga dituntut untuk memiliki teknik dan kemampuan mengingat pekerjaan rutinnya untuk mengatur ruang kantor pimpinan, mengatur jadwal pimpinan, menerima surat masuk dan keluar, mendistribusikan surat, mengarsipkan, memfaximile dan menerima telepon masuk atau keluar.

Sekretaris harus mampu menangani pekerjaan yang dilimpahkan kepadanya secara baik serta bertanggung jawab terhadap pekerjaan itu. Sekretaris sebagai elemen dari sebuah perusahaan, bahkan sebagai tangan kanan pimpinan, sebagai orang yang dipercaya untuk menjaga rahasia dan membantu menyelesaikan tugas pimpinan. Untuk itu sekretaris harus memiliki keterampilan atau keahlian kerja, mempunyai kepribadian yang menarik dan menguasai pengetahuan yang berkaitan dengan tugas dan perannya sebagai seorang sekretaris.

Menurut Poewadarminta (Dalam Saiman, 2002 : 37) mengatakan peran ialah sesuatu yang menjadi bagian atau yang memegang pimpinan utama, yaitu sesuatu yang dapat menetukan terjadinya suatu peristiwa atau kegiatan selanjutnya. Sehingga peranan sekretaris dinilai sangat penting dalam kegiatan yang harus dilakukan selanjutnya oleh pimpinan. Peranan sekretaris tentunya juga tidak terlepas dari fungsi-fungsi yang harus dilakukan oleh seorang sekretaris. Peranan sekretaris ini juga tentunya berbeda antara sesuai dengan jabatan sekretaris pada masing-masing organisasi, lembaga ataupun kantor. Untuk menjamin kelancaran tugas pimpinan maka diperlukan tenaga seorang sekretaris yaitu sekretaris yang terdidik, terampil, mampu memahami serta mengertahui dengan tepat tugas pokok organisasi dan pimpinannya.

Dengan latar belakang pemikiran yang demikian ditambah dengan keinginan penulis untuk 
Volume 1, Nomor 2 November 2019 Program Studi D3 Perpustakaan FISIP UMMAT

mendalami pengetahuan mengenai dunia kesekretariatan serta ingin mengetahui lebih lanjut tugas dan pekerjaan sekretaris dalam memperlancar tugas pimpinan. Untuk itu penulis mengambil judul "Peran Sekretaris Dalam Memperlancar Tugas Pimpinan Pada Dinas Perindustrian Provinsi Nusa Tenggara Barat"

\section{B. METODE PENULISAN}

Penelitian ini menggunakan metode kualitatif. Creswell (2016) mendefinisikan penelitian kualitatif sebagai metode-metode untuk mengeksplorasi dan memahami makna yang oleh sejumlah individu atau sekelompok orang- dianggap berasal dari masalah sosial atau kemanusiaan Proses penelitian kualitatif ini melibatkan upaya-upaya penting, seperti mengajukan pertanyaan-pertanyaan dan prosedurprosedur, mengumpulkan data spesifik dari para partisipan, menganalisis data secara induktif mulai dari tema yang khusus ke tema-tema umum, dan menafsirkan makna data. Pada penelitian ini kompleksitas persoalan yang mencoba untuk diterjemahkan adalah tentang peran sekretaris dalam memperlancar tugas pimpinan.

Pembahasan mengenai para partisipan dan lokasi penelitian dapat mencakup empat aspek yang dinyatakan oleh Miles dan Huberman (1994 dalam Creswell, 2014), yaitu: setting (lokasi penelitian), aktor (siapa yang akan diobservasi atau diwawancarai), peristiwa (kejadian apa saja yang dirasakan oleh aktor yang akan dijadikan topik wawancara dan observasi), dan proses (sifat peristiwa yang dirasakan oleh aktor dalam lokasi penelitian). Sehingga dalam penelitian ini, teknik pemilihan informan yang digunakan adalah nonprobability sampling dengan purposive sampling dimana informan yang dipilih disesuaikan dengan kebutuhan data penelitian. Data pada penelitian ini terdiri dari data primer dan data sekunder.

Data primer diperoleh dari informan melalui pengamatan, observasi dan wawancara mendalam. Selanjutnya hasil dari pengamatan observasi, dan wawancara mendalam dituangkan dalam bentuk uraian rinci dan kutipan langsung. Data sekunder diperoleh dari informasi tertulis, data-data dan literatur-literatur yang mendukung kebutuhan data. Data primer dan data skunder sifatnya saling melengkapi sehingga hasil penelitian lebih akurat. Berikut adalah tabel mengenai jenis dan sumber data dalam peneltian ini.

Selanjutnya, peneliti mengambil lokasi penelitian di Dinas Perindustrian Provinsi Nusa Tenggara Barat. Pertimbangan pemilihan lokasi ini karena menurut penulis di kantor ini akan mudah mendapatkan data dan informasi yang diperlukan dalam menyusun artikel ini dan juga lokasi penelitian ini mudah dijangkau.

Analisa hasil penelitian dilakukan dengan mengorganisasikan data, mereduksi data, dan menyajikan data dalam bentuk bagan, tabel, atau pembahasan secara deskriptif. Creswell, (2014) menjelaskan bahwa analisis data dalam penelitian kualitatif dimulai dengan menyiapkan dan menorganisasikan data (yaitu data teks seperti transkrip, atau data gambar seperti foto) untuk analisis, kemudian mereduksi data menjadi tema melalui proses dan peringkasan kode, dan terakhir menyajikan data dalam bentuk bagan, tabel, atau pembahasan.

\section{LANDASA TEORI}

\section{Pengertian Sekretaris}

Sekretaris berasal dari kata secretum dalam bahasa latin yang artinya something hidden atau rahasia. Dalam bahasa latin, orang yang memegang rahasia disebut dengan secretarium atau secretaries, dalam Bahasa Perancis disebut secretaire, dalam Bahasa Belanda disebut secretares, dan dalam Bahasa Inggris disebut secretary. Berdasarkan arti katanya maka seorang sekretaris dihubungkan dengan secret atau rahasia, yaitu seseorang yang bias menyimpan rahasia.

Menurut Yatimah (2013:33) menyatakan bahwa Sekretaris adalah seseorang yang dapat 
dipercaya oleh pimpinan dalam membantu mempelancaran pekerjaan, terutama untuk penyelenggaraan kegiatan administratif yang menunjang kegiatan manajerial pimpinan atau kegiatan operasional perusahaan, serta membantu pimpinan dalam membina tata hubungan (komunikasi) dengan bawahan maupun pihak lain yang berkepentingan dengan perusahaan.

Adapun pendapat Herlambang dan Marwoto (2014:8), menyatakan bahwa seorang sekretaris adalah seseorang yang diberikan sebuah kepercayaan dan mampu menerima sebuah kepercayaan dari seseorang pimpinan dalam rangka membantu memperlancar pekerjaan, berkaitan dengan penyelenggaraan atau operasional sebuah kegiatan administrasi kegiatan, korespondensi, menerima informasi yang terbaru, menjalin komunikasi yang baik dengan semua pihak yang terlibat dalam sebuah organisasi atau perusahaan. Sekretaris dibutuhkan oleh setiap organisasi untuk membantu pekerjaan dalam bidang organisasi dan kedinasan, atau dengan kata lain, melaksanakan fungsi perkantoran agar pimpinan bisa berkonsentrasi dan melaksanakan tugas-tugas manajerialnya dengan baik.

Menurut Wursanto (Dalam Saiman, 2002 : 31), bahwa sekretariat adalah satuan organisasi atau lembaga yang melaksanakan jasa-jasa perkantoran dalam bidang ketatausahaan. Dengan pengertian tersebut sehingga satuan organisasi yang dimaksud mencakup adanya unsur-unsur :

Tempat untuk dapat terselenggaranya kerja dari pekerjaan yang dipimpin oleh seorang sekretaris.

Manusia atau para pegawai pelaksana, pencipta tata cara dan tata kerja.

Alat atau sarana yang diperdulikan demi tercapainya kelangsungan kerja dari sekretaris dan para bawahannya.

Jadi dapat disintesiskan dari beberapa pendapat diatas bahwa seorang sekretaris harus membantu pimpinannya untuk memperlancarkan pekerjaan administratif dan membina hubungan komunikasi dengan bawahan ataupun pihak lain yang berkepentingan dengan perusahaan. Seorang sekretaris, ini sangat dipercaya oleh pimpinan untuk memegang rahasia perusahaan. Oleh karena peran sekretaris sangatlah penting karena sekretaris adalah “tangan kanan"nya pimpinan, sekretaris juga harus bisa bertanggung jawab dengan semua tugasnya dan harus bisa berkomunikasi dengan baik.

\section{Jenis-jenis Sekretaris}

Pengertian sekretaris juga tergantung dari macam-macam sekretaris karena setiap macam sekretaris memiliki peran dan fungsi yang berbedabeda. Sekretaris dapat dibedakan menjadi beberapa macam, tergantung dari sudut peninjauannya.

1. Jenis sekretaris berdasarkan luas lingkup kerja dan tanggung jawab

a. Sekretaris Organisasi

Sekretaris organisasi disebut juga sekretaris instansi, sekretaris perusahaan, business secretary, excecutive secretary. Seorang sekretaris oganisasi di samping menjalankan tugas atas perintah pimpinan, juga memiliki kedudukan sebagai manajer yang mengelola suatu unit kerja dalam bidang kesekretariatan. Oleh karena itu, seorang sekretaris organisasi memiliki peran dan fungsi manjerial, meliputi membuat perencanaan, melakukan pengorganisasian, membimbing dan mengarahkan, mengontrol serta mengambil keputusan atas berbagai masalah yang dihadapi dalam bidang pekerjaan kesekretariatan.

* Ciri-ciri sekretaris organisasi adalah:

1) Merencanakan apa yang harus dikerjakan dalam rangka business perusahaan atau jawatan di mana dia bekerja.

2) Menyusun struktur dan tata cara organisasi.

3) Memimpin or ganisasi (sekretariat) dengan baik.

Contoh: Sekretaris Jendral pada Lembaga Tinggi Negara

b. Sekretaris Pimpinan

Sekretaris pimpinan sering disebut private secretary, dan ada pula yang menyebutkannya 
dengan istilah personal secretary, meskipun kedua istilah tersebut memiliki makna yang berbeda dalam peran dan tugasnya. Seorang sekretaris pimpinan tidak berkedudukan sebagai seorang manajer sehingga ia tidak menjalankan fungsi-fungsi manajerial. Sekretaris pimpinan dalam kedudukannya merupakan seorang pembantu pimpinan yang bertugas memperingan, mempermudah, memperlancar tugas pekerjaan dan tanggung jawab pimpinan. Ia berstatus sebagai seorang pegawai pada instansi, lembaga, atau perusahaan dan dengan sendirinya ia harus tunduk dan terikat pada peraturan yang berlaku di lembaga, instansi, atau perusahaan tersebut.

* Tugas dan pekerjaan seorang sekretaris pimpinan adalah :

1) Telephoning

2) Surat-menyurat atau korespondensi

3) Filling atau kearsipan

4) Menerima dikte

5) Membuat perjanjian dengan tamu untuk keperluan pimpinan

6) Membuat undangan

7) Menyiapkan rapat pimpinan

8) Membuat agenda kegiatan pimpinan

Contoh: Sekretaris Presiden

c. Sekretaris Pribadi

Sekretaris pribadi adalah seorang sekretaris yang tidak berstatus sebagai pegawai dan tidak digaji oleh organisasi atau perusahaan, tetapi dipekerjakan dan digaji oleh seseorang untuk membantu menagani pekerjaan dan urusan pribadi orang yang mempekerjakannya, yang juga disebut sebagai private secretary atau personal secretary. Contoh: Sekretaris seorang bintang film, penyanyi, atau artis

2. Jenis sekretaris berdasarkan kemampuan dan pengalaman bekerja

a. Sekretaris Junior

Sekretaris junior adalah sekretaris yang masih muda, dapat juga berarti sekretaris yang masih berpangkat atau berkedudukan rendah, muda dalam pengalaman, belum memiliki banyak pengalaman, atau baru saja diangkat sebagai pegawai dengan jabatan sebagai sekretaris. Tugas yang diberikan kepada sekretaris junior adalah tugas khusus dalam bidang sekretariat, misalnya korespondensi, mengetik, steno, menerima dikte, dan sebagainya.

a.Sekretaris Senior

Sekretaris senior adalah yang memiliki masa kerja, pengalaman kerja, kemampuan, dan prestasi kerja sebagai sekretaris yang mandiri, tidak tergantung pada perintah pimpinan. Dan mampu mengatasi berbagai masalah yang dihadapi sehingga benar-benar mampu menunjukkan diri sebagai seorang sekretaris yang profesional.

3. Jenis sekretaris berdasarkan spesialisasi/ bidang khusus dalam pekerjaan

Sekretaris bidang adalah sekretaris yang memiliki tugas dalam bidang tertentu, misanya:

a. Sekretaris dalam bidang sosial dan politik

b. Sekretaris dalam bidang kesejahteraan rakyat

c.Sekretaris dalam bidang administrasi pemerintahan umum

d. Sekretaris dalam bidang hukum, dan sebagainya.

\section{Fungsi Sekretaris}

Dalam menjalankan tugas-tugasnya, seorang sekretaris mempunyai fungsi yangdapat dikelompokkan ke dalam tiga fungsi utama seperti dikutip dari Herlambang dan Marwoto (2014:9) yang menyatakan bahwa:

a. Fungsi sekretaris berdasarkan ruang lingkup tugas sekretaris. Berdasarkan ruang lingkup sekretaris, fungsi sekretaris dapat dibagi menjadi dua yaitu :

1) Fungsi primer. Fungsi primer seorang sekretaris adalah memberikan jasa administratif penunjang kegiatan operasional organisasi perusahaan atau unit organisasi melalui keterampilan, meliputi 
kegiatan seperti pengetikan, penanganan telepon, serta pengelolaan surat dan arsip, agenda, penggandaan;

2) Fungsi sekunder. Fungsi sekunder seorang sekretaris adalah ikut menjamin kelancaran kegiatan organisasi atau perusahaan dan tanggung jawab atas aktivitas rutin kantor, menggunakan pengetahuan bisnis, perbankan, statistik, keuangan, hubungan antar manusia, komunikasi, teknik persiapan rapat.

b. Fungsi sekretaris berdasarkan kedudukan sekretaris dalam organisasi. Berdasarkan kedudukan sekretaris dalam organisasi, fungsi sekretaris merupakan seorang staf atau karyawan, resepsionis, operator telepon, pengarsipan dokumen, pengetik, pembantu pimpinan, dan seorang sekretaris public relation officer.

c. Fungsi sekretaris berdasarkan hubungan sekretaris dengan pimpinan. Berdasarkan hubungan sekretaris dengan pimpinan, fungsi sekretaris adalah sebagai penjaga manajer atau pimpinan, asisten pribadi, pesawat, dan penasehat. Hubungan sekretaris dan pimpinan sangat dekat dan bersifat profesional berkaitan dengan pekerjaan di kantor.

\section{Tugas Sekretaris}

Tugas seorang sekretaris sangat kompleks, dalam pengertian bahwa volume kerja cenderung tinggi dan sangat beraneka ragam, sehingga sekretaris dituntut untuk gesit, tangkas, kerja keras, tegar, dan mampu bersikap dewasa. Adapun tugas-tugas sekretaris menurut Ursula Ernawati (2004:14) pada dasarnya dikelompokkan menjadi :

1. Melaksanakan tugas-tugas rutin

2. Melaksanakan tugas-tugas insidential berdasarkan instruksi

\section{Melaksanakan tugas-tugas kreatif}

Berikut ini uraian lebih jelas mengenai masing-masing dari tugas-tugas sekretaris diatas :
1. Tugas rutin

Yaitu tugas yang setiap hari dihadapi dan dilaksankan tanpa perlu menunggu perintah dari pimpinan atau tanpa menunggu waktu sudah harus diselesaikan sesuai dengan job description-nya. Tugas rutin sekretaris menurut Ursula Ernawati (2004:15) mencakup :

a) Membuka surat masuk untuk pimpinan

b) Menyusun/membuatkan surat untuk kepentingan pimpinan (korespondensi)

c) Menerima tamu dan bertamu mewakili pimpinan

d) Menerima telepon dan menelpon

e) Mengerjakan filing (berkas)

f) Mengatur jadwal (agenda) pimpinan

g) Menjaga kebersihan dan kerapihan kantor untuk menciptakan kenyamanan kerja

h) Menyiapkan pembuatan laporan

i) Mengelola kas kecil (petty cash)

2. Tugas insidental

Yaitu tugas yang tidak setiap hari dihadapi oleh sekretaris. Tugas ini dilaksanakan hanya apabila ada instruksi khusus dari pimpinan. Tugas melaksanakan instruksi (tugas-tugas khusus) menurut Ursula Ernawati (2004:15) yaitu :

a) Mempersiapkan rapat (mulai dari menyusun daftar orang yang akan diundang, membuat surat undangan, mengatur ruangan rapat serta menyediakan segala bahan yang dibutuhkan untuk rapat tersebut).

b) Mengatur makan siang atau makan malam pimpinan dengan relasinya.

c) Menyusun makalah, pidato untuk pimpinan.

d) Mengurus masalah dengan bank

e) Mendatangi perusahaan lain atau instansi pemerintah untuk mencari informasi atau menyampaikan informasi.

f) Mengurus perjalanan dinas pimpinan (mulai dari pemesanan tiket, booking hotel, menyusun agenda perjalanan pimpinan sampai pada catatan pengeluaran biaya perjalanan dinas).

g) Menyusun surat-surat yang bersifat rahasia. 


\section{Tugas kreatif}

Yaitu tugas yang tidak rutin tetapi atas inisiatif sendiri tanpa perintah pimpinan namun wajib untuk dilaksanakan dengan baik dan penuh tanggung jawab. Beberapa contoh tugas kreatif menurut Ursula Ernawati (2004:17) yaitu :

a) Mengirimkan bunga atau surat ucapan selamat kepada rekan pimpinan yang memperoleh promosi jabatan

b) Membuat kliping iklan atau artikel yang dibutuhkan perusahaan

c) Mengumpulkan brosur, price list dari berbagai macam pameran yang berguna untuk perusahaan

d) Mempelajari organisasi, peraturan kerja, product knowledge, budaya perusahaan

e) Mengembangkan diri dengan mengikuti berbagai macam pelatihan, lokakarya, seminar ataupun kursus-kursus maupun pendidikan yang menunjang pekerjaan.

Sedangkan menurut Rosidah (2005:24), tugas sekretaris dikelompokkan dalam 4 kegiatan, yaitu :

1) Tugas rutin, yakni tugas yang tidak memerlukan perintah khusus, perhatian khusus atau pengawasan khusus. Misalnya : tugas pengurusan surat, menerima tamu, tata kearsipan, membuat jadwal kerja pimpinan dan menerima telepon.

2) Tugas khusus, yaitu tugas yang memerlukan perintah atau sesekali pimpinan menginginkan sekretaris menggunakan pertimbangan dan pengalaman sekretaris untuk menyelesaikannya. Misalnya : membuat perjanjian, mengirim facsimile.

3) Tugas yang bersifat kreatif, yaitu tugas yang berasal dari inisiatif sekretaris itu sendiri. Biasanya hal-hal yang dilakukan sekretaris adalah pekerjaan yang mendukung atau menunjang kerja pimpinan dalam menyelesaikan tugas.
4) Tugas untuk melakukan hubungan dan kerjasama, dalam hal ini meliputi :

a. Hubungan kerjasama dengan dunia luar

b. Hubungan kerjasama di dalam organisasi

Selain diatas, ada pula menurut Durotul Yatimah (2009:40) tugas sekretaris dilkelompokkan menjadi 4 kelompok besar, yaitu :

1) Tugas rutin

Merupakan tugas-tugas umum yang hampir tiap hari dihadapi tanpa menunggu instruksi khusus dari pimpinan atau tanpa menunggu waktu harus dilaksanakan sesuai aturan yang diterapkan dalam uraian tugasnya. Biasanya dilakukan secara berskala atau rutin (setiap hari/minggu/bulan) dan umumnya tercantum dalam uraian tugas (job descriptions).

Contoh tugas rutin adalah mengurus dan mengendalikan surat, korespondensi, menangani dan menata arsip, melayani tamu kantor, menangani tamu dan bertamu, menelpon dan menerima telepon, mengatur jadwal kegiatan pimpinan, dan membuat laporan, serta mebuat notulen atau risalah rapat.

2) Tugas instruksi

Merupakan tugas yang tidak selalu tiap hari dilaksanakan oleh sekretaris, tetapi hanya dilaksanakan oleh sekretaris bila ada instruksi khusus dari pimpinan. Contoh yang termasuk ke dalam tugas instruksi adalah mempersiapkan rapat, membuat notulen rapat, membuat konsep surat keluar, mempersiapkan perjalanan dinas, dan mengurus hal-hal tertentu di bank.

3) Tugas kreatif

Merupakan tugas atau pekerjaan yang dilaksanakan atas prakarsa sekretaris sendiri. Dengan demikian, seorang sekretaris yang berdaya guna dan berhasil guna harus penuh inisiatif dan dinamis. Tugas tersebut dilakukan guna meringankan beban pekerjaan atau menciptakan efisiensi dan efektivitas kerja. Contoh tugas kreatif adalah membuat rencana kerja sekretaris, mempelajari pengetahuan tentang perbankan, pemantapan kepribadian, efisiensi kerja, 
pengembangan diri sekretaris, dan memahami peraturan/keadaan organisasi tempat kerja.

4) Tugas koordinatif

Merupakan tugas yang diartikan sebagai penyampaian kegiatan-kegiatan secara teratur untuk mewujudkan keseluruhan waktu dan arah yang tepat dalam pelaksanaan sehingga terdapat tindakantindakan yang seragam dan serasi untuk mencapai tujuan yang telah ditetapkan. Tujuan tugas koordinatif ini adalah melakukan koordinasi dengan orang lain agar tugasnya terlaksana dengan baik dan menjaga arus komunikasi dengan orang lain guna menumbuhkan hubungan baik.

\section{Peran Sekretaris}

Anggapan bahwa peran seorang sekretaris dalam suatu perusahaan atau organisasi itu gampang merupakan anggapan yang salah. Seorang sekretaris bertugas untuk meringankan tugas pimpinan maka dapat dibayangkan jika pimpinan harus mengerjakan segala macam korespondensi, mengangkat telepon, menerima semua tamu dan mengingat segala rencana kegiatannya dalam sehari pasti akan sangat mengganggu kelancaran tugasnya sebagai seorang pemimpin perusahaan. Kedudukan sekretaris dalam membantu produktivitas kerja pimpinan harus bisa menjalankan peran yang sudah menjadi tanggungjawabnya sebagai sekretaris.

Menurut Saiman (2002:37) peranan sekretaris secara umum yaitu sebagai berikut :

1. Peranan sekretaris terhadap atasan

a. Sebagai perantara atau saluran komunikasi dan pembinaan hubungan yang baik bagi orang yang ingin berhubungan dengan pimpinan.

b. Sebagai sumber informasi yang diperlukan pimpinan dalam memenuhi fungsi, tugas dan tanggung jawab.

c. Sebagai pelanjut keinginan pimpinan kepada bawahan dalam pelaksanaan tugas.

d. Alternatif pemikiran dari pimpinan dalam ide-ide. e. Sebagai faktor penunjang dalam keberhasilan pekerjaan dan cerminan pimpinan bagi bawahan.

2. Peranan sekretaris terhadap bawahan

a. Penentuan kebijakan yang berlaku bagi pegawai bawahan secara adil yaitu mengenai pengaturan penempatan pegawai yang sesuai dengan kecakapan dan kemampuan (rule of the place).

b. Memberikan motivasi kerja kepada pegawai bawahan sehingga pekerjaan dapat berjalan lancer dan berhasil baik.

c. Memberikan rasa bangga dan puas kepada pegawai bawahan dalam menjalankan pekerjaan.

d. Menerima pendapat dan usul bawahan dalam berbagai masalah.

e. Mengadakan pendekatan kepada pegawai bawahan untuk lebih megerahkan dan mengetahui kelemahan dan kehendak pegawai bawahan.

Sukses tidaknya sekretaris tidak saja ditentukan oleh ketrampilan melakukan pekerjaan, tetapi ditentukan pula kerjasama dengan pimpinan. Sekretaris dituntut menguasai kecakapan perkantoran, mampu diserahi tanggung jawab tanpa pengawasan langsung oleh pimpinan, berinisiatif serta mampu menilai keadaan kantor dan mengambil keputusan yang perlu selama masih dalam area wewenangnya. Sekretaris harus mengenal pimpinan dengan baik dan menaruh hormat serta loyal kepadanya. Menurut Hartiti (2004:6) menyebutkan peranan sekretaris sebagai berikut :

1. Penjaga/Beranda Perusahaan

Sekretaris harus bisa mnyeleksi setiap tamu yang datang untuk bertemu dengan pimpinan dan mengatur jadwalnya agar tidak bertabrakan.

2. Filter dan Pengelola Informasi

Segala informasi yang masuk harus diolah terlebih dahulu oleh sekretaris. Kemudian mencari, mengolah, menyimpan, mengatur, dan 
bila diperlukan mencari informasi-informasi yang dibutuhkan pimpinan.

3. Asisten Pribadi/Tangan Kanan Pimpinan

Sekretaris membantu pimpinan dalam tugas sehari-hari bahkan untuk banyak kesempatan mewakili pimpinan untuk keperluan perusahaan.

4. Secret Keeper/Pemegang Rahasia

Sekretaris yang baik menyadari bahwa ia memiliki informasi yang tidak boleh diteruskan kepada pihak yang tidak berhak.

5. Penasehat untuk dimintakan berbagai pendapat.

6. Penghubung/Humas

Sekretaris berdiri diantara pimpinan dan pihak lain. Untuk itu sekretaris harus pandai menjabarkan kebijakan pimpinan ataupun menjadi penyampai informasi dari luar.

7. Perawat/Pelindung

Walaupun bersifat pribadi, sekretaris harus memperhatikan keselamatan dan kesehatan pimpinan termasuk di dalamnya menciptakan suasana kerja yang menyenangkan sehingga pimpinan tidak cepat lelah.

Pada dasarnya setiap sekretaris mempunyai peranan yang sama, yaitu membantu kelancaran pelaksanaan tugas pimpinan. Dalam melaksanakan tugas tersebut sekretaris tidak hanya berhubungan dengan pimpinannya saja, melainkan juga dengan klien perusahaan, karyawan lain, bahkan juga dengan pekerjaan yang ditekuninya.

Menurut Priansa (2004:24) peran sekretaris secara umum yaitu sebagai berikut :

a. Peran Sekretaris bagi Organisasi. Sekretaris organisasi, di samping bekerja atas instruksi pimpinan, jugamemiliki wewenang untuk membantu melakukan fungsi manajemen, karena ia juga berperan sebagai manajer.

b. Peran Sekretaris Bagi Pimpinan. Sekretaris pimpinan sering disebut juga dengan sekretaris pembantu pimpinan. Sekretaris ini berperan untuk membantu pimpinan organisasi sehingga peran yang diembannya mampu terlaksana dengan baik, sesuai dengan tujuan organisasi. Sekretaris pimpinan merupakan

c. Peran Sekretaris Bagi Pegawai. Sekretaris merupakan jembatan langsung antara pimpinan dan pegawai yang memiliki peran penting.

Sekretaris memegang peranan yang penting dan dapat menentukan berhasil tidaknya tujuan perusahaan. Pentingnya peranan seorang Sekretaris ini tentunya sesuai dengan jabatan Sekretaris pada masing-masing organisasi. Peranan Sekretaris secara umum dapat diketahui sebagai berikut :

1. Peranan Sekretaris terhadap atasan yaitu :

a. Sebagai perantara saluran komunikasi dan pembinaan hubungan yang baik bagi orang yang Ingin berhubungan dengan pimpinan.

b. Sebagai sumber informasi yang diperlukan pimpinan dalam memenuhi fungsi, tugas, dan Tanggung jawab.

c. Sebagai pelanjut keinginan pimpinan kepada bawahan dalam pelaksanaan tugas.

d. Alternatif pemikiran dari pimpinan dalam ide-ide.

e. Sebagai faktor penunjang dalam keberhasilan pekerjaan dan cerminan pimpinan dan bawahan.

2. Peranan Sekretaris terhadap bawahan (pimpinan) :

a. Penentuan kebijakan yang berlaku bagi pegawai bawahan secara adil, yaitu :

1. Mengenai peraturan penempatan pegawai yang sesuai dengan kecakapan dan kemampuan.

2. Memberikan motivasi kerja kepada pegawai bawahan sehingga pekerjaan dapat berjalan lancar dan berhasil dengan baik.

3. Memberikan rasa bangga dan puas kepada pegawai bawahan dalam menjalankan pekerjaan. 
4. Menerima pendapat dan usul bawahan dalam berbagai masalah

5. Mengadakan pendekatan kepada pegawai bawahan untuk lebih mengerahkan dan mengetahui kelemahan dan kehendak pegawai bawahan.

b. Peranan Sekretaris terhadap bawahan merupakan penilaian dari bawahan sehingga sikap dan tingkah laku Sekretaris akan berpengaruh terhadap pekerjaan pegawai bawahan. Bagi Sekretaris yang ramah dan komunikatif akan memberikan suasana hubungan kerja yang baik bagi bawahan sehingga segala permasalahan dapat didiskusikan dan dicari cara penyelesaiannya. Berkaitan dengan peranan Sekretaris dalam menjalankan tugas dan fungsi jabatannya, hal yang sangat penting adalah mengenai pendekatan yang dapat dilakukan oleh seorang Sekretaris. Beberapa cara seorang Sekretaris dalam mengadakan pendekatan kepada pegawai bawahan, yaitu:

1) Memberi perintah atau instruksi kepada bawahan secara resmi, baik secara lisan maupun tertulis.

2) Mengadakan pengawasan secara langsung pada saat-saat tertentu kepada pegawai bawahan yang sedang melaksanakan tugasnya.

\section{PEMbahasan}

Peran adalah pola kerja, perbuatan, penilaian, sikap dan gaya hidup yang diharapkan dari seseorang sesuai dengan kedudukan, tugas dan tanggung jawabnya. Karena kedudukan, tugas dan tanggung jawab, keadaan diri dan keadaan hidup berbeda-beda, maka dalam hidup orang dapat mempunyai beberapa peran yang berbeda pula. Misalnya seseorang dapat berperan sebagai direktur perusahaan, ketua RT, kepala keluarga, sekretrais dan lain-lain.
Peran yang dipegang sekretaris berporos pada kedudukan atau statusnya dalam lembaga, perusahaan, organisasi, yayasan tempat dia bekerja. Pimpinan yang dibantu sekretaris dapat berfungsi dalam kegiatan utama atau kedua, karena tugas sekretaris membantu pimpinan, maka entah pimpinan itu ada pada kegiatan lembaga utama yang pertama atau kedua, peran sekretaris adalah peran pendukung.

Menurut Susanto (Dalam Sukoco, 2006 : 24) ada tiga peran dari seorang sekretaris, yaitu:

1. Sebagai pusat informasi, sekretaris menjalankan fungsi strategisnya di dalam organisasi dengan memberikan pengaruh positif pada status dan performasi perusahaan melalui kelancaran arus informasi internal maupun eksternal.

2. Melalui peran teknisnya, sekretaris juga mampu menunjang kinerja pimpinan dengan meyalurkan informasi yang jelas dan akurat sebagai bahan pengambilan keputusan.

3. Sedangkan peran pendukung, sekretaris adalah memberikan pengaruh positif bagi anggota organisasi lainnya dengan mendisribusikan informasi secara cepat dan tepat sasaran.

Dalam Saiman (2002 : 37) peran sekretaris secara umum:

1. Peran sekretaris terhadap atasan

a. Sebagai perantara atau saluran komunikasi dan pembinaan hubungan yang baik bagi orang yang ingin berhubungan dengan pimpinan.

b. Sebagai sumber informasi yang diperlukan pimpinan dalam memenuhi fungsi, tugas, dan tanggung jawab.

c. Sebagai pelanjut keinginan pimpinan kepada bawahan dalam pelaksanaan tugas.

d. Alternatif pemikiran dari pimpinan dalam ide-ide.

e. Sebagai faktor penunjang dalam keberhasilan pekerjaan dan cerminan pimpinan bagi bawahan.

2. Peran sekretaris bagi bawahan 
a. Penetuan kebijakan yang berlaku bagi pegawai bawahan secara adil yaitu mengenai pengaturan penempatan pegawai yang sesuai dengan kecakapan dan kemampuan.

b. Memberikan motivasi kerja kepada pegawai bawahan sehingga pekerjaan dapat berjalan lancar dan berhasil baik.

c. Memberikan rasa bangga dan puas kepada pegawai bawahan dalam menjalankan pekerjaannya.

d. Meneriman pendapat dan usul bawahan dalam berbagai masalah.

e. Mengadakan pendekatan kepada pegawai bawahan untuk mengerahkan dan mengetahui kelemahan dan kehendak pegawai bawahan.

Jadi, peranan sekretaris terhadap bawahan juga merupakan penilaian dari bawahan sehingga bagaimana sikap dan tingkah laku sekretaris akan berpengaruh terhadap pekerjaan pegawai bawahan. Bagi sekretaris yang ramah dan komunikatif tentunya akan memberikan suasana hubungan kerja yang baik bagi bawahan, sehingga segala permasalahan kiranya dapat didiskusikan dan dicari cara penyelesaiannya.

Adapun yang menjadi peran seorang sekretaris dalam memperlancar tugas pimpinan pada Dinas Perindustrian Provinsi Nusa Tenggara Barat adalah :

1. Mengelolah surat-surat masuk, memberikan nomor surat, dan menyediakan lembar disposisi bagi pimpinan, sehingga pimpinan mudah untuk memberikan perintah tertulis terkait dengan surat-surat.

2. Mengagendakan dan mendistribusikan suratsurat yang lembar disposisinya telah diisi oleh pimpinan ke kabid maupun kasi yang ditujukan oleh pimpinan.

3. Mengatur persiapan saat akan dilaksanakannya rapat dengan relasi maupun para kabid dan kasi.
4. Menyiapkan segala keperluan pimpinan apabila akan melaksanakan perjalanan dinas keluar daerah salah satunya membuat SKPD.

5. Sebagai perantara saluran komunikasi dan pembinaan hubungan baik bagi organisasi yang ingin berhubungan dengan pimpinan.

6. Sebagai sumber informasi yang diperlukan pimpinan dalam memenuhi fungsi, tugas dan tanggung jawab.

7. Sebagai pelanjut keinginan pimpinan kepada karyawan/ti dalam melaksanakan tugas.

8. Memberikan informasi dan arahan kepada karyawan/ti lain apabila mendapati kesulitan.

Tujuan langsung pelaksanaan peran sekretaris adalah mendukung agar pimpinan dapat melaksanakan tugas dengan baik. Sedangkan tujuan tak langsungnya adalah tercapainya tujuan lembaga, karena pelaksanaan tuga pimpinan yang dibantunya bertujuan membantu lembaga mencapai tujuan. Sekretaris pada Dinas Perindustrian Provinsi Nusa Tenggara Barat mempunyai peran yang sangat penting dalam membantu kelancaran tugas pimpinan, apabila sekretaris tidak ada maka pekerjaan akan terhambat baik dalam segi tenaga, pikiran dan waktu sehingga berkurangnya efisiensi kerja. Saat ini kedudukan sekretaris dalam perusahaan semakin penting disebabkan perkembangan zaman yang semakin pesat dengan permasalahan yang kompleks. Dengan sendirinya pimpinan tidak dapat mengendalikan perusahaan itu sendiri.

Seorang sekretaris pada Dinas Perindustrian Provinsi Nusa Tenggara Barat mempunyai peranan dalam memberikan informasi, baik secara formal maupun informal. Informasi formal yang berhubungan dengan perusahaan, sedangkan informasi informal yang berhubungan dengan segala hal diluar perusahaan yang dibutuhkan pimpinan dalam melaksanakan tugas. Jadi perlu diingat bahwa seorang sekretaris yang baik harus dapat bekerja secara efisien. Dengan demikian seorang sekretaris 
harus selalu berusaha menemukan cara yang lebih mudah dalam menggunakan pikiran, cara kerja yang lebih cepat dalam penggunaan waktu, cara kerja yang lebih hemat dalam menggunakan benda.

Peran sekretaris yang tidak kalah pentingnya didalam organisasi adalah untuk memecahkan masalah dalam perusahaan dan menyederhanakan pelaksanaan pekerjaan untuk memperlancar tugas pimpinan. Begitu besarnya peran sekretaris bagi organisasi sehingga ia dituntut untuk bisa tampil pada situasi apapun untuk itu dibutuhkan seorang sekretaris yang bermutu tinggi. Dalam hubungan kerjasama peran sekretaris sangat strategis dalam memberikan dukungan semangat kerja pimpinan. Untuk itu sekretaris harus berusaha mengenal pimpinannya. Seperti sifat pimpinan, adat kebiasaan, hobi serta kekuatan dan kelemahannya, cara dan kemajuan kerjanya, apa yang diperlukan untuk pekerjaannya.

Dalam Sulistiyani dan Rosidah (2005 : 137) mengatakan bahwa untuk dapat bekerjasama dengan pimpinan maka yang dilakukan sekretaris antara lain :

1. Bisa memelihara wibawa pimpinan

2. Sebagai bayangan atasannya untuk selalu memelihara kebijakan manajemen

3. Selalu siap untuk memberikan pendapat bila diperlukan

4. Berusaha memahami maksud atasan, yaitu berusaha memahami tanggung jawab atasan dan membantu melaksanakan dengan cara :
a. Melancarkan pekerjaan dengan perencanaan yang baik
b. Membagi tugas sesuai dengan keahlian karyawan
c. Mengumpulkan pendapat dan mempertimbangkan dari semua karyawan
d. Menciptakan gairah kerja dengan ketersediaan menerima gagasan-gagasan
e. Memelihara sistem kontrol dari kesinambungan kegiatan manajemen
f. Menangani masalah-masalah human relation

g. Menciptakan suasana berpikir positif

h. Memelihara hubungan baik dengan relasirelasi

i. Menghadiri acara yang berkaitan dengan bisnisnya

Membina hubungan yang baik dengan pimpinan perlu dilakukan karena sekretaris merupakan orang yang selalu dekat dengan pimpinan dan siap membantu pimpinan dalam menyelesaikan tugas pimpinan. Untuk itu sekretaris harus mengenal pimpinannya lebih dalam, bagaimana cara berfikir dan cara pandang akan suatu hal, bagaimana pola kepemimpinannya, bagaimana kepribadiannya, bagaimana pimpinan menjalin hubungan baik dengan relasi pimpinan atau rekan kerja dan masih banyak lagi yang harus diketahui oleh seorang sekretaris.

Hubungan sekretaris dengan kepala atau pimpinan Dinas Perindustrian Provinsi Nusa Tenggara Barat terjalin secara baik dan harmonis, dimana sekretaris sudah memahami benar tentang bagaimana pimpinannya berpikir, bagaimana kepribadian pimpinannya, bagaimana pimpinan menjalin hubungan baik dengan relasi atau rekan kerja. Sedangkan hubungan antara sekretaris dengan

relasi pimpinan, keluarga pimpinan, rekan kerja baik yang berupa staf maupun dengan yang lainnya cukup berjalan dengan efektif, lancar, dan terorganisir dengan baik. 
Volume 1, Nomor 2 November 2019 Program Studi D3 Perpustakaan FISIP UMMAT

\section{E. KESIMPULAN}

Dari hasil penelitian yang dilakukan oleh penulis, maka dapat ditarik kesimpulan yang berkaitan dengan Judul Peran Sekretaris Dalam Memperlancar Tugas Pimpinan Pada Dinas Perindustrian Provinsi Nusa Tenggara Barat yaitu sebagai berikut :

1. Untuk menjadi seorang sekretaris yang profesional harus memiliki kemampuan dan keterampilan teknis yang harus dikuasai oleh seorang sekretaris seperti kemampuan mengetik cepat, keahlian dalam mengoperasikan komputer, kemampuan bahasa Inggris yang baik, kemampuan mengatur waktu.

2. Sebagai seorang sekretaris juga harus memiliki kemampuan berkomunikasi dan berinteraksi. Karena tugas sekretaris berhubungan dengan berbagai macam individu yang masing-masing berbeda latar belakang, berbeda status sosial, berbeda kepentingan, berbeda kedudukan, maka sekretaris dituntut untuk mampu memahami pihak-pihak yang berhubungan dengannya.

3. Sekretaris pimpinan di Dinas Perindustrian Provinsi Nusa Tenggara Barat adalah sebagai pembantu pimpinan yang pekerjaannya antara lain menangani administrasi surat-surat, mengarsipkan surat/dokumen penting, serta melaksanakan tugas-tugas lainnya yang sifatnya membantu pimpinan.

4. Peran sekretaris di Dinas Perindustrian Provinsi Nusa Tenggara Barat sangat penting, disamping sebagai pembantu pimpinan, sekretaris juga merupakan penghubung antara pimpinan dan pekerja-pekerja serta seluruh staff dan publik dimana peran penghubung ini menjadikan sekretaris dapat menciptakan dan memelihara bisnis kantor dengan lancar.

\section{DAFTAR PUSTAKA}

Creswell, J. W. (2014). Penelitian Kualitatif \& Desain Riset. Yogyakarta: Pustaka Pelajar.

Ernawati, Ursula. 2004. Pedoman Lengkap Kesekretarisan untuk Sekretaris dan Calon Sekretaris.Yogyakarta: Graha Ilmu.

Herlambang, Susatyo dan Bambang Heru Marwoto. 2014. Manajemen Kesekretariatan: Cara mudah memahami dan mengelola pekerjaan kesekretariatan. Yogyakarta: Gosyen Publishing.

Priansa, Donni Juni. 2014, Kesekretariatan Profsional Berkompeten cerdas Terampil Melayani. Bandung: Alfabeta.

Rosidah dan Ambar Teguh Sulistiyani. 2005. Menjadi Sekretaris Profesional dan Kantor yang Efektif.Yogyakarta: Gava Media.

Saiman. 2002, Manajemen Sekretaris. Jakarta: Ghalia Indonesia. Saiman. 2002, Manajemen Sekretaris. Jakarta: Ghalia Indonesia.

Sumantro, Rumsari Hadi dan Lukas Dwiantara. 2006. Sekretaris Profesional: Yogyakarta: Kanisius.

Yatimah, Durotul. 2013. Kesekretarisan Modern dan Administrasi Perkantoran. Bandung: CV. Pustaka Setia 